\title{
PENCIPTAAN PRODUK BATIK ECO FRIENDLY DENGAN TEMA KENDARAAN TRADISIONAL KHAS YOGYAKARTA PIT ONTHEL (SEPEDA KAYUH) SEBAGAI UPAYA PENGUATAN INDUSTRI KREATIF KERAKYATAN DAN PARIWISATA
}

\author{
Sugeng Wardoyo¹ (swardoyo13@yahoo.com, Institut Seni Indonesia yogyakarta) \\ Isbandono Hariyanto ${ }^{2}$ (Institut Seni Indonesia yogyakarta) \\ Titiana Irawani ${ }^{3}$ (Institut Seni Indonesia yogyakarta)
}

\begin{abstract}
This article has title "Design of Eco Friendly Batik Products with traditional vehicle Pit Onthel (bicycle) theme as effort Yogyakarta Folk Creative Industry and Tourism. Yogyakarta city known called as bicycle city, because it was many people used to ride bicycle as traditional vehicle beside andong and becak. Recently has changed habit in use transportation models. Eco friendly batik products which is used natural dyes or non synthetic dyes. This product suitable to be applied, because it has high price, at the same time reduces the negatife impact of environment. So that Design of eco friendly batik products is an positive inovation, because demand of batik products also getting increase.
\end{abstract}

Keywords: eco friendly, creative batik, natural dyes, traditional vehicle

\begin{abstract}
ABSTRAK
Artikel ini berjudul "Desain Produk Batik Ramah Lingkungan dengan tema kendaraan tradisional Pit Onthel (sepeda) sebagai upaya Industri Kreatif dan Pariwisata Rakyat Yogyakarta. Kota Yogyakarta dikenal dengan sebutan kota sepeda, karena sudah banyak orang mengendarai sepeda sebagai kendaraan tradisional di samping andong dan becak. Baru-baru ini telah mengubah kebiasaan dalam menggunakan model transportasi. Produk batik ramah lingkungan yang digunakan pewarna alami atau pewarna non sintetis. Produk ini cocok untuk diterapkan, karena memiliki harga tinggi, sekaligus mengurangi dampak negatif terhadap lingkungan. Sehingga Desain produk batik ramah lingkungan adalah inovasi positif, karena permintaan produk batik juga semakin meningkat.
\end{abstract}

Kata kunci: ramah lingkungan, batik kreatif, pewarna alami, kendaraan tradisional

\section{PENDAHULUAN}

Kota Yogyakarta merupakan kota dengan segudang predikat. Sebutan kota budaya dan kota pelajar begitu melekat. Tidaklah mengherankan karena wilayah ini dahulu merupakan salah satu wilayah pusat pemerintahan kerajaan Mataram Islam di pulau Jawa yang sarat dengan nilai dan sejarah budaya, sehingga otomatis pula wilayah ini merupakan pusat kegiatan dan pengembangan kebudayaan. Kebudayaan sendiri dapatlah diartikan secara luas dalam konotasi positif sebagai ujud perilaku manusia yang berakal dan berbudi, baik itu berupa produk seni, etika, dan peradaban. Kondisi lingkungan kota Yogyakarta yang sangat kondusif menjadikannya sebagai salah satu daerah yang nyaman dan aman untuk dihuni, sesuai dengan slogan kota ini, yaitu "Jogja Berhati Nyaman."

Seperti diketahui bersama, bahwa Yogyakarta dikenal sebagai pusat kebudayaan dengan potensi yang melimpah ruah nyaris tak terbatas. Berbagai macam bentuk dan produk seni dan budaya dapat ditemui di daerah ini. Kota Yogyakarta dahulu juga dikenal dengan julukan sebagai kota sepeda karena memang banyak masyarakat umum yang mempergunakan moda transportasi tradisional yang satu ini, di samping moda transportasi tradisional lain yang cukup dikenal seperti becak dan andong. Namun akhir-akhir ini telah terjadi pergeseran budaya dalam 
penggunaan kendaraan tradisional tersebut. Penggunaan sepeda kayuh atau juga dikenal sebagai pit onthel ini misalnya yang mulai banyak ditinggalkan, karena banyak yang beralih ke sepeda motor dan mobil pribadi. Memang faktor pertumbuhan perekonomian dan kesejahteraan masyarakat yang semakin meningkat menjadi salah satu faktor utama. Kesejahteraan masyarakat yang meningkat memiliki konsekuensi logis yang nampak pada semakin banyaknya masyarakat yang mampu membeli kendaraan bermotor khususnya roda dua, sehingga mampu menggeser penggunaan sepeda sebagai alat transportasi yang utama. Dampak negatif yang sangat terasa akhir-akhir ini adalah kemacetan dan polusi udara yang semakin meningkat. Hal ini apabila tidak disikapi secara bijaksana, ke depan bukan tidak mungkin akan dapat mengganggu tingkat kualitas kemurnian dan kesehatan udara di wilayah ini.

Isu utama mengenai dampak negatif dari polusi udara yang ditimbulkan oleh semakin banyaknya kendaraan bermotor juga makin gencar didengungkan. Sudah ada upaya positif yang dilakukan oleh pihak pemerintah kota dengan menggalakkan program Sego Segawe atau Sepeda Kanggo Mangkat Sekolah Lan Nyambut Gawe (sepeda untuk berangkat sekolah dan bekerja) di bawah kepemimpinan Heri Zudianto ketika menjabat sebagai Wali Kotamadya Yogyakarta dalam dua periode secara berturut-turut. Program yang hingga kini masih berlanjut adalah sebagai sebuah upaya atau terobosan untuk merevitalisasi dan menggalakkan kembali penggunaan moda transportasi tradisional, terutama sepeda bagi masyarakat luas untuk tetap menjaga kebersihan dan kesehatan udara, serta menekan tingkat polusi udara yang semakin meningkat. Program ini khususnya diperuntukkan bagi para pegawai di lingkungan pemerintah kota agar lebih memilih naik sepeda ketimbang naik kendaraan bermotor. Syukurlah program ini pun kini juga sudah mulai diadopsi oleh pemerintahan Propinsi DKI Jakarta di bawah kepemimpinan Gubernur Joko Widodo (Jokowi) dan mudah-mudahan dapat ditularkan pula di wilayah lain.

Sebagai kota budaya, Yogyakarta juga sangat dikenal sebagai salah satu sentra kerajinan batik di Indonesia. Batik sudah sejak dahulu dikenal di daerah ini terutama semenjak menjadi wilayah yang menjadi pusat budaya yang utama, warisan dari kerajaan Mataram di tanah Jawa. Akhir-akhir ini eksistensi batik menunjukkan kemajuan yang cukup menggembirakan. Terlebih setelah batik secara resmi telah diakui sebagai world heritage oleh UNESCO pada tahun 2009. Dengan diakuinya batik Indonesia oleh dunia internasional ini, maka perlu disikapi secara konsekuen khususnya bagi para seniman dan pelaku usaha di bidang ini agar terus berupaya dan berusaha untuk menjaga serta melestarikan, bahkan mengembangkannya.

Pada saat ini batik di kota Yogyakarta memang terus mengalami perkembangan, namun demikian perkembangannya dipandang belum maksimal, karena masih banyak pelaku industri batik atau perajin yang memproduksi batik dengan desain yang kurang kompetitif. Kebanyakan desainnya masih cenderung monoton dan masih melulu mengacu pada motif-motif tradisional semata. Hal inilah yang mengakibatkan poduk-produk semacam itu menjadi kurang kompetitif, yang otomatis pula kurang diminati oleh selera pasar yang selalu dinamis. Termasuk pula di dalam penggunaan bahan warna yang diterapkan, mayoritas masih mempergunakan bahan pewarna sintetis atau kimiawi yang notabene adalah bahanbahan yang dapat merusak lingkungan sekitar.

Potensi pasar bagi produk batik dan potensi kepariwisataan di wilayah kota Yogyakarta sangatlah menjanjikan, apalagi didukung dengan predikat sebagai kota tujuan wisata terbesar kedua setelah Bali. Langkah strategis yang dapat dilakukan untuk mengantisipasi sekaligus mengatasi agar produk batik yang diproduksi dapat menjawab selera pasar yang dinamis sehingga mampu memiliki daya saing produk yang diperhitungkan terutama di era pasar global seperti sekarang ini, salah satu caranya adalah dengan melakukan upaya terobosan melalui penciptaan dan pengembangan produk batik yang inovatif dengan mengambil tema seni budaya lokal, di antaranya adalah dengan mengangkat kendaraan tradisional di kota Yogyakarta sebagai tema penciptaan produk batik eco friendly atau ramah lingkungan. Hal ini merupakan sebuah langkah dan upaya yang nyata untuk mengangkat nilai tambah khususnya bagi para perajin di wilayah ini.

Produk batik ramah lingkungan adalah produk batik yang mempergunakan bahan baku pewarnaan utama yang berasal dari zat warna alami atau non sintetis. Produk yang dikategorikan sebagai produk go green ini dinilai tepat untuk diaplikasikan, karena selain memiliki nilai jual atau nilai ekonomis yang tinggi, juga dapat mengurangi dampak kerusakan lingkungan. Hal ini mengingat dampak buruk jangka panjang penggunaan bahan sintetis secara masif dalam memproduksi batik secara masal, secara lambat laun juga akan berpengaruh pula pada kelangsungan ekosistem di wilayah ini. Oleh karena itu penciptaan produk batik ramah lingkungan atau berbasis eco friendly ini merupakan sebuah upaya terobosan atau inovasi positif, mengingat kebutuhan akan produk batik juga terus meningkat.

Berdasarkan uraian di atas, maka dipandang perlu diupayakan sebuah penelitian tersendiri guna mewadahi sekaligus menjawab berbagai persoalan tersebut di atas. Kendaraan tradisional khas 
Yogyakarta yaitu pit onthel (sepeda kayuh), akan dijadikan sebagai dasar/sumber inspirasi dalam penciptaan produk batik eco friendly dengan tetap mengutamakan ciri khas batik Yogyakarta yang tetap melekat, baik itu dari aspek visualisasinya maupun yang berkaitan dengan keteknikannya. Pengangkatan salah satu aset budaya lokal ini diharapkan dapat menghasilkan produk-produk batik baru yang inovatif dengan karakteristik atau spesifikasi berdasarkan kearifan seni budaya lokal setempat, guna meningkatkan sektor ekonomi kreatif kerakyatan dan menunjang sektor industri pariwisata. Di sisi lain kegiatan penelitian ini juga sedikit banyak ikut berperan aktif baik secara langsung maupun tidak langsung dalam mengkampanyekan atau merevitalisasi penggunaan moda transportasi tradisional khas Yogyakarta yang tidak menimbulkan polusi atau pencemaran udara, sekaligus juga menggalakkan produk dengan nilai ekonomis yang tinggi namun tetap berwawasan lingkungan.

Metode penelitian yang diterapkan dalam penelitian ini adalah metode penciptaan karya seni, yang merupakan sebuah metode yang lazim dipergunakan dalam penciptaan karya seni rupa pada umumnya.

\section{KAIIAN LITERATUR}

Penelitian terdahulu yang secara khusus mengenai penciptaan produk batik eco friendly atau batik ramah lingkungan belum banyak ditemukan, khususnya yang mengangkat tema kendaraan tradisional khas Yogyakarta. Selama ini tulisan atau hasil penelitian yang ada kebanyakan adalah tentang penciptaan karya seni rupa termasuk batik, tentang pelestarian dan pengembangan seni dan budaya bangsa secara umum, dan kajian mengenai kendaraan tradisional khas Yogyakarta, namun secara khusus belum diangkat sebagai sebuah penciptaan karya seni rupa khususnya motif dan produk batik. Walaupun demikian, hasil-hasil penelitian tersebut apabila ditambah dan dilengkapi dengan referensi lainnya akan sangat membantu dalam usaha pencarian data bagi penelitian ini. Adapun hasil-hasil penelitian dan referensi yang dimaksudkan adalah sebagai berikut.

Sebuah buku menarik dengan judul Pit Onthel: Pameran Sepeda Lama: 21-28 Maret 2006 (Wuryani, ed., 2006), memaparkan beberapa aspek kajian mengenai sepeda. Penyajian tulisan dan dokumentasi tentang sepeda disajikan ke dalam berbagai perspektif, di antaranya adalah sejarah sepeda, macam dan jenis sepeda, dan merek-merek sepeda yang dilengkapi dengan berbagai foto dan dokumentasi para kolektor sepeda, termasuk iklaniklan mengenai sepeda. Menariknya, buku yang merupakan katalog pameran ini juga memperinci bagian-bagian dari sepeda seperti bagian lampu, sadel, pegangan tangan, kunci, pedal, emblem logo sepeda dari berbagai merek, asesoris pelengkap seperti tas, ikat pinggang, dan lain sebagainya. Meskipun tidak mengangkat sepeda sebagai sumber ide penciptaan karya seni rupa, namun berbagai informasi dalam buku ini dapat memberikan kontribusi data yang sangat bermanfaat bagi penelitian ini.

Dalam artikel ilmiah dengan judul Transportasi Tradisional (Kereta Kuda, Becak, dan Sepeda Onthel) yang ditulis oleh Restu Apriantini Asnanda (2012) diutarakan mengenai moda transportasi tradisional tanpa mesin dan bahan bakar yang sudah ada semenjak masa lampau dan hingga kini masih bisa dijumpai. Beberapa di antaranya disebutkan, yaitu kereta kuda, becak, dan sepeda onthel sebagai cikal bakal transportasi modern yang kita kenal sekarang ini. Artikel ini memberikan pembahasan yang bersifat informatif mengenai definisi alat transportasi tradisional berupa kereta kuda, becak, dan andong yang cukup bermanfaat. Di samping itu artikel ini juga dilengkapi dengan beberapa dokumentasi/foto yang dapat dijadikan data visual sehingga dapat menunjang data dalam penelitian ini.

Artikel yang berjudul Beberapa Masalah Angkutan Kota: Suatu Kasus Transportasi di Kota Padat Penduduk, membeberkan beberapa informasi mengenai kondisi transportasi perkotaan. Dalam artikel ini dirumuskan mengenai istilah angkutan kota dan masalah angkutan umum dan pribadi. Tulisan ini secara khusus menyoroti timbulnya berbagai permasalahan kota padat penduduk yang kompleks, kaitannya dengan adanya tata kelola transportasi perkotaan (Soekotjo, 1974). Artikel ini meskipun berbeda dari aspek kajiannya dengan penelitian ini, namun sejatinya sejalan dengan tujuan yang ingin dicapai, yaitu mengharapkan adanya penataan transportasi yang baik dan terkendali agar tidak berdampak negatif bagi kelangsungan hidup generasi yang akan datang.

Pembahasan yang relevan dengan seni batik dikemukakan dalam Batik: Spirit of Indonesia. Dikatakan bahwa batik tidak bisa dipisahkan dengan siklus kehidupan (daur hidup) orang Jawa, yang mencerminkan jiwa masyarakat pendukungnya. Batik disoroti dari berbagai dimensi, yaitu dari aspek sejarah batik yang menjelaskan keberadaannya di Indonesia hingga menjadi salah satu tradisi penting yang mengakar sedemikian kuat, khususnya bagi masyarakat Jawa. Diulas pula tentang pembagian wilayah penghasil batik di Indonesia. Pembahasan mengenai ragam hias batik dan makna simbolisnya disajikan secara cukup menarik. Keberadaan batik di Indonesia juga diperbincangkan dalam konteks kekinian yang menempatkan dinamika batik dalam bidang seni rupa dan batik sebagai mode dalam 
berbusana (Achjadi, 1999). Dalam Ungkapan Sehelai Batik: Batik its Mystery and Meaning karya Nian S. Djoemena (1987), diterangkan mengenai latar belakang terbentuknya ciri-ciri ragam hias batik dari daerah penghasilnya, baik itu dari daerah pedalaman maupun daerah pesisiran. Dikaji pula berbagai macam kain batik dengan ragam hias yang semuanya melambangkan harapan, pesan, niat, dan itikad baik. Hal serupa tertuang dalam buku Indonesia Indah: Batik, oleh Biranul Anas et al., (1997), seni batik ditinjau dari berbagai aspek yang terkait dengan keberadaannya dari berbagai daerah penghasilnya. Diuraikan bahwa perkembangan batik di Indonesia tidak lepas dari adanya beberapa faktor yang melatarbelakangi dan berbagai pengaruh, termasuk pengaruh dari luar. Penjelasan ketiga buku di atas dapat memberikan panduan dasar dalam proses pelaksanaan penelitian ini, kaitannya dengan keberadaan batik sebagai sebuah karya seni rupa.

Topik mengenai batik klasik juga disajikan Hamzuri dalam Batik Klasik: Classical Batik (1985). Buku ini memaparkan perihal seluk-beluk batik klasik di Indonesia, proses pembuatan, dan uraian mengenai ragam hias pada batik klasik yang tersaji lengkap dengan berbagai contohnya. Buku ini dapat memberikan informasi dan masukkan kaitannya dengan berbagai hal teknis dalam proses pembuatan karya batik. Demikian pula dalam Batik: The Impact of Time and Environment karya $\mathrm{H}$. Santoso Doellah (2002), yang menyatakan bahwa perkembangan batik di Indonesia sejak dulu hingga kini, tidak terlepas dari konteks zaman dan pengaruh lingkungannya. Isi buku ini juga mencakup perihal teknik dan proses batik tradisional secara detail dengan sajian visual yang menarik dari berbagai macam koleksi kain batik, sehingga dapat dijadikan acuan dalam pelaksanaan penelitian ini.

Kaitannya dengan perancangan desain motif batik, buku yang berjudul Dasar-Dasar Desain memberikan penjelasan, bahwa untuk membuat suatu desain/komposisi yang baik, maka haruslah memperhatikan beberapa faktor, yaitu kesatuan, keselarasan, keseimbangan, kontras, proporsi, kontras klimaks, dan pewarnaan. Lebih lanjut diuraikan, bahwa untuk dapat membuat suatu susunan rancangan yang menarik, maka perlu diketahui cara menciptakan hubungan keluasan yang baik, membuat perubahan-perubahan bentuk dalam penglihatan sesuai dengan yang dikehendaki dan untuk menentukan besarnya ukuran yang harus dipahami serta perbandingan yang baik (Murtihadi dan Gunarto, 1981/1982). Buku ini akan digunakan sebagai pedoman dalam pembuatan desain motif batik. Di samping itu permasalahan desain juga dibahas dalam buku yang berjudul Dasar-Dasar Tata Rupa dan Desain (Sanyoto dan Sadjiman, 2005), yang dapat dijadikan pelengkap acuan dasar dalam proses perancangan agar dapat menghasilkan perancangan yang menarik.

Buku yang secara khusus mengulas mengenai penciptaan motif batik, salah satu di antaranya adalah Motif Batik Kreasi Baru Khas Yogyakarta: Candi, Wayang, dan Keris sebagai Sumber Inspirasi. Buku ini menguraikan tentang penciptaan motif batik kreasi baru khas Yogyakarta dengan menggali hasil seni dan budaya lokal yang ada di kota Yogyakarta. Diutarakan tentang bagaimana proses kreatif penciptaan motif batik itu dilakukan hingga dihasilkannya berbagai desain motif batik yang disajikan secara rinci dan lengkap dengan gambar yang menarik (Kusumawati dan Widodo, 2012). Buku ini sejalan dengan penelitian ini, meskipun sama-sama mengangkat budaya dan kearifan lokal di kota Yogyakarta, namun demikian berbeda dari segi objek materialnya maupun luarannya. Produk batik yang dibahas dalam buku ini masih mempergunakan bahan warna sintetis, sedangkan penelitian ini merancang produk batik dengan warna alami untuk memenuhi kriteria sebagai produk batik eco friendly atau ramah lingkungan.

\section{METODE}

Metode penelitian yang diterapkan dalam penelitian ini adalah metode penciptaan karya seni, yang merupakan sebuah metode yang lazim dipergunakan dalam penciptaan karya seni rupa pada umumnya. Dalam tahapan pelaksanaannya, metode penciptaan ini kemudian dapat dibagi menjadi tiga tahap, yaitu:

\section{Tahap Eksplorasi}

Tahap eksplorasi merupakan sebuah tahap awal yang dilaksanakan guna menggali data yang diperlukan. Kegiatan ini dilakukan dengan metode studi pustaka, observasi, dan wawancara.

Studi pustaka adalah kegiatan pengumpulan data khususnya tentang kendaraan tradisional khas Yogyakarta, yaitu pit onthel (sepeda kayuh). Kegiatan pengumpulan data ini dilakukan dengan cara mendatangi berbagai perpustakaan, yaitu perpustakaan di beberapa perguruan tinggi yang dianggap representatif, perpustakaan di wilayah kota Yogyakarta seperti perpustakaan Balai Kajian Jarahnitrah, perpustakaan Museum Negeri Sonobudoyo Yogyakarta, perpustakaan Kolese St. Ignatius, perpustakaan kota Yogyakarta, perpustakaan Balai Penelitian Batik dan Kerajinan, perpustakaan Keraton Yogyakarta, dan perpustakaan lain yang dipandang relevan dengan topik penelitian. Data ini juga dapat diperoleh melalui internet guna menambah pengayaan dan perbendaharaan data. Data yang diperoleh dari studi pustaka ini berupa data tertulis maupun data visual berupa gambar atau foto 
dari berbagai sumber pustaka, baik yang tertuang dalam buku-buku terbitan, majalah, laporan penelitian, artikel, dan publikasi ilmiah lainnya.

Observasi adalah kegiatan pengamatan secara langsung terhadap objek penelitian yang meliputi kendaraan tradisional khas Yogyakarta, yaitu pit onthel (sepeda kayuh). Observasi dilakukan di tempattempat atau lokasi penggunaan moda alat transportasi tradisional tersebut, yaitu meliputi kawasan wisata seperti seputaran Malioboro, Alunalun Utara, Alun-alun Selatan, lokasi sekitar Ngasem, seputaran Keraton Yogyakarta, seputaran wilayah Kotagede, dan lain sebagainya. Kegiatan ini dilakukan guna mendapatkan gambaran secara kongkrit tentang objek-objek tersebut. Bersamaan dengan kegiatan observasi tersebut, sudah barang tentu dilakukan kegiatan pendokumentasian/pengambilan gambar/foto dari objek-objek tersebut.

Wawancara dilakukan kepada para narasumber yang dianggap mampu memberikan penjelasan tentang objek yang diteliti. Dari kegiatan ini didapatkan data lisan yang dapat dimanfaatkan untuk melengkapi data tertulis, data foto, maupun data gambar hasil dari kegiatan studi pustaka dan observasi di lapangan.

Penelitian ini mempergunakan analisis deskriptif. Seluruh data tertulis dan lisan yang diperoleh melalui studi pustaka dan wawancara disajikan dalam bentuk uraian. Sementara itu data yang berupa gambar atau foto disajikan dalam bentuk data visual. Seluruh data yang berhasil dikumpulkan tersebut kemudian dianalisis untuk selanjutnya dijadikan acuan dasar dalam proses perancangan motif batik.

\section{Tahap Perancangan}

Tahap perancangan adalah tahap pembuatan desain motif batik yang dilaksanakan melalui beberapa tahap, yaitu: (a) proses pembuatan sket alternatif; (b) pemilihan sket alternatif; dan (c) pembuatan desain jadi.

\section{Tahap Perwujudan}

Tahap perwujudan merupakan tahap mewujudkan desain jadi menjadi prototipe produk batik eco friendly, yang diwujudkan dalam bentuk karya batik tulis yang secara khusus mempergunakan bahan pewarna alami yang ramah lingkungan.

\section{HASIL DAN PEMBAHASAN}

\section{Tinjauan Umum Tentang Pit Onhel (Sepeda Kayuh)}

Roda merupakan salah satu temuan manusia yang cukup penting. Dengan ditemukannya roda, maka diciptakanlah sejumlah alat transportasi yang dikenal hingga zaman modern saat ini. Awalnya roda memiliki bentuk sederhana, yaitu berupa lempengan kayu seperti roda gerobak, kemudian berjeruji, selanjutnya roda kereta kuda, baru kemudian sepeda. Tahun 1791 sepeda dari kayu mulai dibuat di Perancis. Pada tahun 1817 Baron Von Drais de Sauerbrun membuat sepeda kayu tanpa pedal yang pertama dan kemudian populer di Jerman, Perancis, Inggris, dan Amerika. Dua dasawarsa kemudian bentuk sepeda sudah nampak nyaman untuk dikendarai. Semenjak itu bermunculan sejumlah merk dan bentuk sepeda dari negara-negara Eropa yang kemudian disusul oleh Asia seperti China dan Jepang.

Sepeda atau dalam bahasa Jawa disebut pit onthel apabila dilihat secara etimologis berasal dari kata fiets, dan onthel artinya kayuh, sehingga pit onthel dapat diartikan sebagai sepeda kayuh. Sepeda masuk sebagai alat transportasi di Indonesia belum dapat dikatakan lama, yaitu sekitar awal abad ke-20 pada tahun 1910-an. Sewaktu pertama kali masuk tentu saja dipakai oleh pegawai kolonial dan para bangsawan, baru kemudian para misionaris dan saudagar kaya bisa memilikinya.

Sepeda, pertama kali dibuat memiliki bentuk yang berbeda dengan sepeda pada zaman sekarang. Sepeda yang pertama kali dibuat di Perancis pada tahun 1791, bentuknya aneh. Sepeda ini roda depannya dibuat dalam posisi paten dan tidak memiliki pedal. Sepeda jenias ini baru bergerak maju ketika pengemudinya menggerakkan kakinya untuk berjalan maju. Pada tahun 1817, Baron von Drais de Sauerbrun menyempurnakan model sepeda. Meskipun tanpa pedal, namun sepeda yang ini sudah berkerangka kayu. Selain itu juga sudah memiliki tempat duduk dan tempat meletakkan tangan di depan. Sepeda ini dapat dikemudikan dengan sebuah palang yang disambungkan dengan roda depan. Saat itu, bersepeda menjadi populer di Jerman, Perancis, Amerika, dan Inggris. Sepeda model ini dikenal dengan sebutan sepeda kuda-kudaan.

Pada tahun 1839 untuk pertama kali diciptakan sepeda berpedal oleh Kirkpatrick Macmillan, seorang pandai besi dari Skotlandia. Ciptaannya ini bukan sekedar memperbaiki model lama tapi betul-betul sebuah inovasi baru, sepeda dengan pedal kaki untuk menjalankan rodanya. Roda bagian depan yang dapat dikemudikan diapit dengan kerangka dari logam dalam posisi vertikal yang dilekatkan dengan kerangka bagian depan yang terbuat dari kayu yang tersambung dengan roda bagian belakang. Pedal berada pada kedua sisi kiri dan kanan tersambung dengan tangkai pengungkit perseneling yang naik turun memutar untuk menggerakkan roda belakang. Temuan Macmillan ini membuktikan bahwa kendaraan roda dua dapat digerakkan dengan kayuhan kaki tanpa pengemudi kehilangan keseimbangannya (Wuryani, 2006: 55-22)

\section{Tinjauan Zat Pewarna Alami Untuk Batik}


Yang dimaksud zat warna alam, pada hakekatnya adalah zat-zat warna yang diolah dan disarikan atau diekstrasikan dari bahan tumbuhtumbuhan seperti daun, buah, kulit kayu, batang kayu, getah, umbi-umbian seperti kunir, dan akar-akaran lainnya.

\section{Bahan pembantu}

Tawas $\left(\mathrm{K}_{2} \mathrm{Al}_{2} \mathrm{O}_{4}\right)$, Tawas atau alumunium $\mathrm{K}_{2} \mathrm{Al}_{2} \mathrm{O}_{4}$ merupakan salah satu hasil tambang, yang dapat digunakan sebagai bahan mordanting paling baik. Selain itu tawas juga digunakan sebagai bahan fiksasi atau pengunci zat warna alam agar tidak luntur ;Tunjung $\left(\mathrm{F}_{2} \mathrm{SO}_{4}\right)$, Tunjung atau zat besi $\mathrm{F}_{2} \mathrm{SO}_{4}$ digunakan sebagai bahan fiksasi atau pengunci zat warna alam agar tidak luntur; Kapur $\left(\mathrm{Ca}_{2} \mathrm{CO}_{3}\right)$, Kapur atau kalsium $\mathrm{Ca}_{2} \mathrm{CO}_{3}$ digunakan sebagai bahan fiksasi atau pengunci zat warna alam agar tidak luntur; Gula Jawa, Gula Jawa digunakan sebagai bahan campuran larutan warna indigofera.

\section{Tahap Perancangan}

Proses penciptaaan motif batik dalam penelitian ini diawali dengan pembuatan sejumlah sket alternatif guna menciptakan motif batik yang baru. Masing-masing dari motif tersebut, pada awalnya terlebih dahulu dibuatkan sket alternatifnya. Berdasarkan sejumlah sket alternatif tersebut kemudian dipilih salah satu untuk disempurnakan atau dibuat menjadi gambar jadi. Pembuatan sket alternatif ini dimaksudkan untuk mencari berbagai kemungkinan terciptanya motif yang menarik dengan berbagai pilihan.

Langkah awal yang dilakukan dalam proses pembuatan sket alternatif ini adalah membuat gambar motifnya terlebih dahulu. Gambar motif dibuat terutama berdasarkan data visual berupa foto. Data yang ada di foto tersebut kemudian diolah dan divisualisasikan kembali hingga menjadi gambar motif yang cocok untuk diterapkan. Motif yang sudah terwujud, selanjutnya disusun hingga menjadi suatu pola tertentu. Di dalam sket alternatif dibuat dengan mempertimbangkan berbagai aspek, antara lain bahan warna yang dipergunakan, teknik, maupun proses perwujudnya. Selain itu juga dengan memperhatikankan prinsip-prinsip desain yang meliputi irama/ritme/keselarasan, kesatuan, dominasi/daya tarik/pusat perha-tian/keunikan, keseimbangan, propor-si/perbandingan/keserasian, kesederha-naan dan kejelasan. Dengan memperhatikan kaidah-kaidah tersebut, maka diharapkan akan tercipta motif batik yang estetis, eksploratif, dan inovatif. Sejumlah sket alternatif yang telah dibuat dari masing-masing motif kemudian dipilih dan diseleksi salah satu yang dianggap paling bagus.
Pembuatan motif batik seluruhnya dikerjakan secara manual. Sketsa yang terpilih kemudian disempurnakan hingga menjadi gambar jadi pola motif batik di atas kertas. Tahap atau langkah pengerjaannya yaitu menyempurnakan garis gambar motif secara manual berdasarkan sketsa alternatif terpilih sehingga terciptalah gambar motif batik.
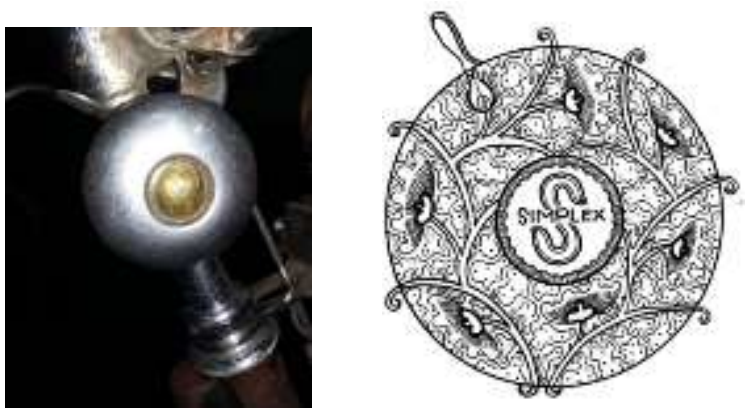

Gambar 1. Bel sepeda Simplex
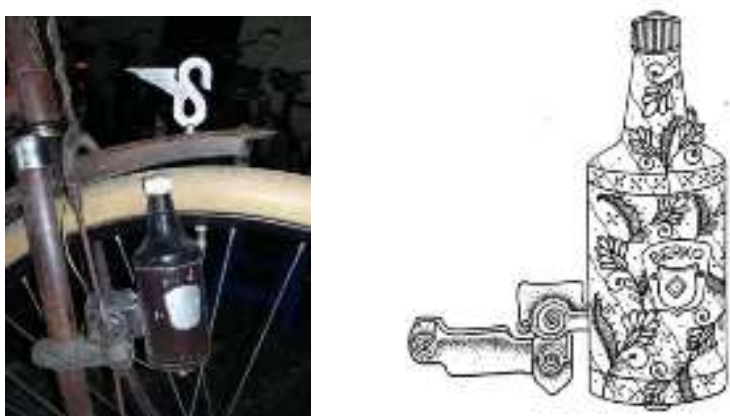

Gambar 2. Dinamo sepeda Simplex
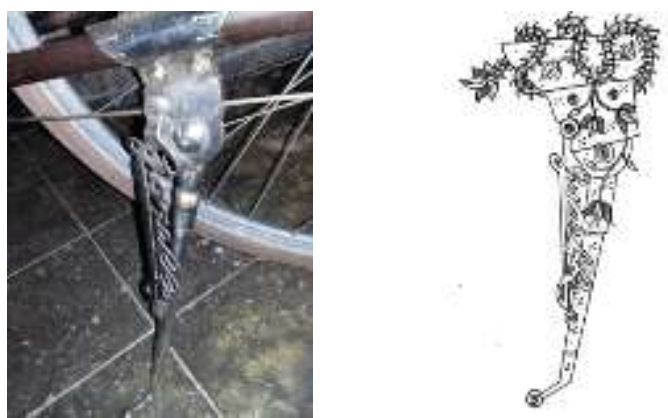

Gambar 3. Standar sepeda Gazelle
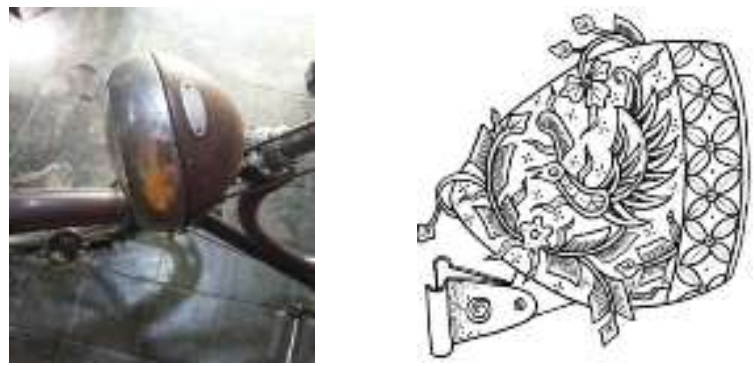

Gambar 4. Lampu sepeda Gazelle 


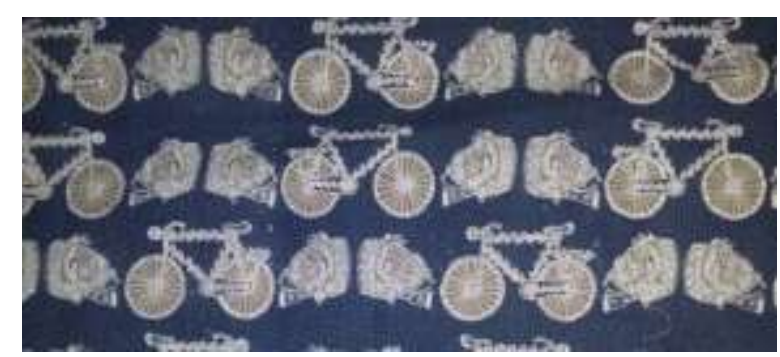

Gambar 5. Prototip 1

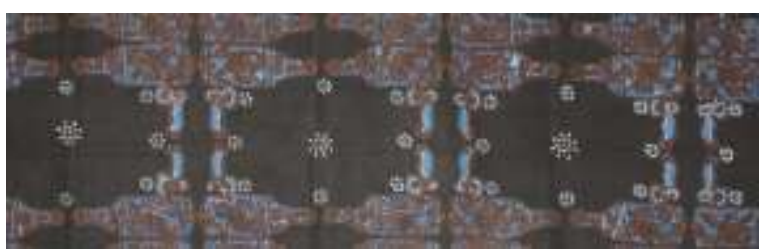

Gambar 6. Prototip 2

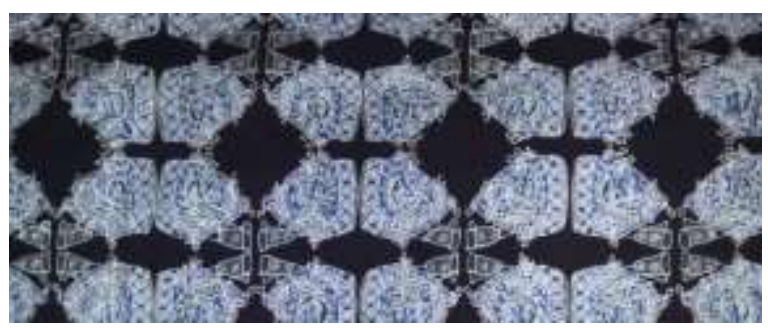

Gambar 7. Prototip 3

PENUTUP

Pengembangan pada prototip produk batik dengan tema pit onthel (sepeda kayuh) sebagai kendaraan tradisional khas Yogyakarta, dapat dilakukan pada beberapa aspek yang meliputi komposisi motif dan penggunaan bahan warnanya. Pengembangan dapat dilakukan dengan mengkombinasikan unsur-unsur dari bagian pit onthel (sepeda kayuh) dalam satu proses perwujudan. Dari produk yang dihasilkan, maka produk batik yang dihasilkan dapat dikombinasikan, dikembangkan, serta dieksplorasi secara terus-menerus secara tidak terbatas. Aspek pengembangan di samping pada aspek motif, juga pada eksplorasi dari bahan warna alam yang digunakan. Hal ini dikarenakan pengembangan motif yang dihasilkan memiliki berbagai peluang nilai artistik dan ekonomis yang tinggi.

\section{DAFTAR PUSTAKA}

Achjadi, Judi, 1999, Batik Spirit of Indonesia, Yayasan Batik Indonesia, Jakarta.
Anas, Biranul, et al., 1997, Indonesia Indah: Batik, Yayasan Harapan Kita, Jakarta.

Asnanda, Restu Apriantini, 2012,"Transportasi Tradisional (Kereta Kuda, Becak, dan Sepeda Onthel)" dalam Media Pembelajaran Geografi, geografiupi2010.blogspot.com/2012/10 / transportasi - tradisional - $\quad$ keretakuda_30.html.

Djoemena, Nian S., 1987, Ungkapan Sehelai Batik: Batik Its Mystery and Meaning, Djambatan, Jakarta.

Doellah, H. Santoso, 2002, Batik: The Impact of Time and Environment, Danar Hadi, Solo.

Hamzuri, 1985, Batik Klasik: Classical Batik, Djambatan, Jakarta.

Kusumawati, Toyibah dan Widodo, Suryo Tri, 2011, Motif Batik Kreasi Baru Khas Yogyakarta: Candi, Wayang, dan Keris sebagai Sumber Inspirasi, Leutikaprio, Yogyakarta.

Murtihadi dan Gunarto, G, 1981-1982, DasarDasar Desain, Bagian Proyek Pengadaan Buku Kejuruan non teknik Departemen Pendidikan dan Kebudayaan, Jakarta.

Sanyoto, Sadjiman, Ebdi, 2005, Dasar-Dasar Tata Rupa dan Desain, CV. Arti Bumi Intaran, Yogyakarta.

Soekotjo, R., 1974, "Beberapa Masalah Angkutan Kota: Suatu Kasus Transportasi di Kota Padat Penduduk,"dalam PRISMA: Masalah \& Kebijaksanaan Kependudukan, No. 2 Th. III April 1974, LP3ES, Jakarta.

Wuryani, M. (ed.), 2006, Pit Onthel: Pameran Sepeda Lama: 21-28 Maret 2006, Bentara Budaya, Yogyakarta. 